\title{
Relationship between the prevalence of anti-glutamic acid decarboxylase autoantibodies and duration of type 1 diabetes mellitus in Brazilian patients
}

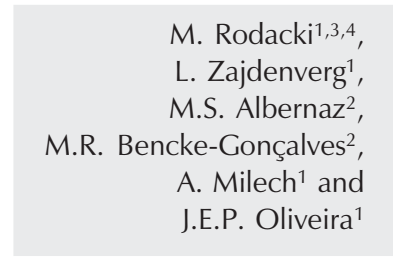

\author{
Serviços de ${ }^{1}$ Diabetes e Nutrologia, and ${ }^{2}$ Medicina Nuclear, \\ Universidade Federal do Rio de Janeiro, Rio de Janeiro, RJ, Brasil \\ ${ }^{3}$ Instituto Estadual de Diabetes e Endocrinologia Luis Capriglione, \\ Rio de Janeiro, RJ, Brasil \\ ${ }^{4}$ Joslin Diabetes Center, Harvard Medical School, Boston, MA, USA
}

Correspondence

M. Rodacki

109 Queensberry St \#12

Boston, MA 02215

USA

E-mail:

melanie.rodacki@joslin.harvard.edu

$\ldots \ldots \ldots \ldots \ldots \ldots \ldots$

Received October 15, 2003 Accepted August 31, 2004

\begin{abstract}
The objective of the present study was to determine whether the duration of disease has any influence on the prevalence of glutamic acid decarboxylase autoantibodies (GADA) in Brazilian patients with type 1 diabetes (T1D) and variable disease duration. We evaluated 83 patients with T1D. All participants were interviewed and blood was obtained for GADA measurement by a commercial radioimmunoassay (RSR Limited, Cardiff, UK). Four groups of patients were established according to disease duration: A) 1-5 years of disease $(\mathrm{N}=24)$, B) 6-10 years of disease $(\mathrm{N}=19), \mathrm{C}) 11-15$ years of disease $(\mathrm{N}=25)$, and $\mathrm{D})>15$ years of disease $(\mathrm{N}=15)$. GADA prevalence and its titers were determined in each group. GADA was positive in 38 patients $(45.8 \%)$ and its frequency did not differ between the groups. The prevalence was 11/24 (45.8\%), 8/19 (42.1\%), 13/25 (52\%), and 6/15 $(40 \%)$ in groups $\mathrm{A}, \mathrm{B}, \mathrm{C}$, and $\mathrm{D}$, respectively $(\mathrm{P}=0.874)$. Mean GADA titer was $12.54 \pm 11.33 \mathrm{U} / \mathrm{ml}$ for the sample as a whole and $11.95 \pm 11.8,12.85 \pm 12.07,10.57 \pm 8.35$, and $17.45 \pm 16.1 \mathrm{U} / \mathrm{ml}$ for groups $\mathrm{A}, \mathrm{B}, \mathrm{C}$, and $\mathrm{D}$, respectively $(\mathrm{P}=0.686)$. Sex, age at diagnosis or ethnic background had no significant effect on GADA (+) frequency. In conclusion, in this transversal study, duration of disease did not affect significantly the prevalence of GADA or its titers in patients with T1D after one year of diagnosis. This was the first study to report this finding in the Brazilian population.
\end{abstract}

\section{Introduction}

Type 1 diabetes mellitus (T1D) is characterized by destruction of B-pancreatic cells. In the vast majority of patients, this is an autoimmune process. Glutamic acid decarboxylase (GAD) is one of the autoantigens
Key words

- Anti-GAD65 auto-antibodies

- Type 1 diabetes mellitus

- Time from diagnosis 
erase, glima 38, and GLUT 2 (1). Autoantibodies against some of these antigens have been used in clinical practice as important tools to elucidate difficult cases, when the classification of diabetes cannot be done solely based on the clinical presentation. Four of them are considered to be the most useful: islet cell cytoplasmic autoantibodies (ICA), insulin autoantibodies (IAA), glutamic acid decarboxylase autoantibodies (GADA), and tyrosine phosphatase autoantibodies (IA-2A). One or more of these markers are present in $85-90 \%$ of individuals with a recent diagnosis of T1D (2).

ICA and IA-2A frequently decline following diagnosis of T1D. Only a few patients have circulating antibodies after 10 years of disease. IAA only has clinical value for diabetes classification if measured before starting treatment with exogenous insulin. Insulin antibody assays do not distinguish spontaneous autoantibodies from antibodies arising from insulin immunization, which commonly appear in patients treated with insulin. Therefore, ICA, IA-2A and IAA have a limited role in the investigation of patients with long-standing disease. On the other hand, GADA appears to remain positive for long periods of time. Antibodies against GAD are detected in $50-85 \%$ of T1D patients with a recent diagnosis (3). Although some investigators have shown a higher prevalence of GADA in newly diagnosed patients than in individuals with a longer duration of diabetes, persistent positive results are found in many cases (3-7). As a matter of fact, GADA appears to be the ideal immune marker in patients already treated with insulin and with long-standing disease.

The aim of the present study was to determine the prevalence of GADA in a group of Brazilian patients with T1D with variable disease duration and to determine if the duration of disease has any influence on GADA frequency or its titers in this population of mixed ethnic background.

\section{Subjects and Methods}

\section{Subjects}

Between March 2002 and November 2002, 91 patients with T1D were recruited at the outpatient clinic of the Clementino Fraga Filho Teaching Hospital, Federal University of Rio de Janeiro, and State Institute of Diabetes and Endocrinology of Rio de Janeiro. T1D was clinically defined on the basis of diabetic ketoacidosis (DKA) at diagnosis or requirement of continuous insulin treatment within one year of diagnosis, with a persistent need of its use during the subsequent year. Patients with any evidence of chronic complications at diagnosis, alcoholism, pregnancy, pancreatic exocrine diseases, end-stage renal disease (8), immunosuppressive diseases, or using immunosuppressive drugs were excluded. Individuals that had stopped insulin therapy for more than two weeks since the diagnosis of diabetes and had not developed DKA were also excluded. Random C peptide was measured in all participants and was used as an exclusion criterion if $>1.5 \mathrm{ng} / \mathrm{ml}$ in patients with the duration of disease $\geq 3$ years, which makes a diagnosis of T1D improbable $(9,10)$.

\section{Methods}

In this transversal study, all patients were interviewed and asked about duration of their disease, age at diagnosis, current insulin dose, and initial presentation of the disease. Blood was sampled for GADA, random $\mathrm{C}$ peptide, and for other exams not related to this study. Before the beginning of the study, informed consent was obtained from all subjects. The study was approved by the Ethics Committees of the participating institutions.

\section{GADA and $C$ peptide measurement}

After blood sampling, serum was obtained by centrifugation and stored at $-70^{\circ} \mathrm{C}$ 
for 1-6 months. GADA was measured by radioimmunoassay with a commercial kit from RSR Limited (Cardiff, UK). Sera were considered to be positive if antibody levels were above $1.0 \mathrm{U} / \mathrm{ml}$. The inter- and intraassay coefficients of variation were 3.5 and $3.1 \%$, respectively. All exams were performed in duplicate. Random C peptide was measured by chemiluminescence with the commercial kit Immulite (Diagnostic Products, Los Angeles, CA, USA) with inter- and intra-assay coefficients of variation of 7.6 and $8.2 \%$, respectively.

\section{Patient groups}

Patients were divided into four groups according to time of diagnosis in four groups: 1) group $A, 1-5$ years of disease $(N=24) ; 2)$ group $\mathrm{B}, 6-10$ years of disease $(\mathrm{N}=19) ; 3)$ group $\mathrm{C}, 11-15$ years of disease $(\mathrm{N}=25)$, and 4) group $\mathrm{D},>15$ years of disease $(\mathrm{N}=$ 15). GADA prevalence and GADA titers were determined in each of these groups.

\section{Statistical analysis}

Data regarding GADA prevalence for the four groups were compared by the chi-square test and mean GADA levels were compared by ANOVA. The correlation between GADA positivity and age at diabetes onset was calculated by the Mann-Whitney U-test and the chi-square test.

\section{Results}

\section{Descriptive data for the study population}

Eight of the 91 individuals were excluded because they had C peptide levels of $>1.5 \mathrm{ng} /$ $\mathrm{ml}$ and three years or more of diabetes. The study population comprised 51 females and 32 males ranging in age from 11 to 59 years (mean: $33.73 \pm 28.48$ ). Mean age at diagnosis was $19.24 \pm 9.46$ years (range: 2 to 49 years) and mean disease duration was 10.67 \pm 7.37 years (range: 1 to 37 years). Fifty-two were white and 31 were Afro-Brazilians (11). Diagnosis was established due to DKA in 30 cases and due to polyuria, polydipsia and nocturia in 51. In 2 individuals, diagnosis was established due to occasional exams.

There were no major differences between groups regarding disease presentation (presence or absence of DKA, $\mathrm{P}=0.67)$, age of onset $(P=0.448)$ or $\operatorname{sex}(P=0.9)$. In group $A$ there was a predominance of non-white individuals $(15 / 24$ or $62.5 \%)$, while the other groups mainly consisted of white patients $(13 / 19$ or $68.4 \%, 19 / 25$ or $76 \%$ and $11 / 15$ or $73.3 \%$ white individuals in groups $\mathrm{B}, \mathrm{C}$ and $\mathrm{D}$, respectively; $\mathrm{P}=0.024$ ). Most individuals $(\mathrm{N}=59$ or $71.08 \%)$ were diagnosed between 10 and 29 years of age in all groups. Fifteen patients $(18.07 \%)$ were diagnosed before 10 years of age. Twenty-seven (32.5\%), 31 $(37.3 \%)$ and $10(12.04 \%)$ individuals were diagnosed between 10 and 19,20 and 29 and $\geq 30$ years of age, respectively. C peptide was $<0.5 \mathrm{ng} / \mathrm{ml}$ in 79 patients $(95.2 \%)$ and $\geq 0.5$ to $\leq 1.5 \mathrm{ng} / \mathrm{ml}$ in three $(3.6 \%)$. Only one patient had C peptide $>1.5 \mathrm{ng} / \mathrm{ml}$ and had been diagnosed one year before the study.

\section{GADA prevalence}

GADA was positive in 38 patients $(45.8 \%)$ and did not decrease as a function of increasing duration of the disease. The prevalence of GADA $(+)$ according to duration of disease was 11/24 (45.8\%), 8/19 (42.1\%), $13 / 25(52 \%)$, and $6 / 15(40 \%)$ for the groups with a duration of disease of 1-5, 6-10, 1115 , and $>15$ years, respectively. There were no significant differences between groups $(\mathrm{P}$ $=0.874)$. There were no correlations between GADA positivity and age at diabetes diagnosis $(\mathrm{P}=0.77)$ or ethnic group $(\mathrm{P}=$ $0.96)$. The prevalence of GADA $(+)$ was $53.8 \%$ in women (28 patients) and $32.3 \%$ in men (10 patients), but this difference was not significant $(\mathrm{P}=0.07)$. There were no significant differences between GADA $(+)$ 
and (-) subjects in the prevalence of DKA at diagnosis. There was no correlation between GADA frequency and $\mathrm{C}$ peptide levels $(\mathrm{P}=$ $0.503)$.

\section{GADA levels}

There was no correlation between GADA values and duration of diabetes in patients with GADA positivity $(\mathrm{P}=0.738)$. Mean GADA titers were $12.54 \pm 11.33 \mathrm{U} / \mathrm{ml}$. GADA levels according to duration of disease were $11.95 \pm 11.8,12.85 \pm 12.07,10.57$ \pm 8.35 , and $17.45 \pm 16.1 \mathrm{U} / \mathrm{ml}$ for groups $\mathrm{A}$, $\mathrm{B}, \mathrm{C}$, and $\mathrm{D}$, respectively $(\mathrm{P}=0.686)$.

\section{Discussion}

Most previous studies have shown that patients with long-standing T1D have lower prevalence of GADA than those with a recent diagnosis. Surprisingly, in the current study, duration of the disease did not influence GADA frequency or its titers in individuals with T1D for one year or more.

One remarkable characteristic of this study population was the low prevalence of serum GADA (45.8\%), with a slightly but not statistically significant higher frequency in women. Similar results were already reported in several groups with long-standing disease, although studies that included only new-onset patients reported much higher frequencies (12-16). We might speculate that the relatively low prevalence of GADA in this group could also be due to a high proportion of patients diagnosed during adulthood, as it was previously suggested that T1D diagnosed in adulthood is associated with a lower frequency of this antibody $(17,18)$. However, in agreement with data reported by Hosszufalusi et al. (19), age of diagnosis did not influence GADA positivity in this study. We cannot exclude the possibility that this antibody could be less prevalent in the Brazilian population, which is a composite of different ethnic groups such as Amerin- dian, Black African and European than in purely Caucasian populations $(11,20-22)$. It is known that GADA tend to be less frequent in Black African patients with T1D (23). On the other hand, previous Brazilian studies have found a similar prevalence of GADA positivity in Brazilian and Caucasian European T1D $(5,24)$. Finally, we believe that the lack of patients with a very recent diagnosis ( $<12$ months) could be a major factor explaining the low prevalence of GADA in our study population, especially in the group with a shorter duration of the disease. One of the criteria used for inclusion in our study protocol was insulin therapy for $\geq 12$ months after diagnosis. Therefore, all the patients included had been diagnosed at least one year before the study. Although we did not find any differences between groups defined according to disease duration in GADA prevalence or its titers, it is possible that GADA levels might have dropped significantly in the first year of disease or even earlier, during the first few months after diagnosis.

Even though the drop of prevalence in the first year of the disease is a possible explanation, most previous studies have reported a higher frequency of GADA in patients with T1D with a shorter duration of the disease regardless of whether this category comprised only individuals diagnosed for less than 1 year $(5,12)$ or included patients with the duration of disease up to five years $(25,26)$. Interestingly, studies that consider $<2$ or $<5$ years of disease in the recent diagnosis category have demonstrated a relatively lower prevalence of the antibody in these groups (54.9-56\%), closer to our results $(25,26)$. Nevertheless, not all investigators have shown remarkable differences between individuals with recent and long-standing disease. Imagawa et al. (7) reported 55.2\% of positivity in recent-onset patients and $42.4 \%$ positivity in the group with longstanding disease. A 5-year longitudinal analysis of GADA frequency and its levels start- 
ing at the time of T1D diagnosis revealed that levels declined with time, but remained positive in most cases (6). Borg et al. (27) also reported a high frequency of persistence of its positivity ( $81 \%$ ) in a 12-year follow-up study. Although the current study has a transversal design, all groups presented a similar prevalence of GADA and similar mean titers, suggesting that the levels could be sustained in this population.

The factors involved in the maintenance of serum GADA are still to be identified. It is uncertain if the persistence is related to some residual ß-cell function (27-29), but in our study, that included mainly patients lacking any insulin secretion, there was no correlation between GADA frequency and B-cell function as evaluated by $\mathrm{C}$ peptide secretion. One factor that might have contributed to our results was the high mean age at diagnosis of T1D. It has been previously suggested that GADA could be more persistent in patients with T1D diagnosed after 15 years of age (30). Finally, there are still controversial issues regarding GADA prevalence and titers along disease progression, as well as the factors that contribute to its persistence in serum. Further longer and larger longitudinal studies could help elucidate these issues.
This was the first Brazilian study to show that the prevalence of GADA and its serum titers do not seem to change significantly after the first year of T1D. This information can be particularly useful for the differential diagnosis of patients with long-standing diabetes mellitus who cannot be classified solely on the basis of clinical findings, and also for the better understanding of the underlying pathogenesis of T1D, especially in patients of mixed ethnic background. Interestingly, although the massive antigen delivery into the circulation that follows $\beta$-cell destruction has already cleared in individuals with long-standing T1D, a significant percentage of these patients still exhibit GADA. This could suggest an ongoing production of the antibody possibly directed at the scarce remaining pancreatic sources of glutamic decarboxylase or at the non-pancreatic form of the enzyme.

In conclusion, in this transversal study, duration of disease did not affect significantly the prevalence of GADA positivity or its titers in patients with T1D after one year of diagnosis. However, further large longitudinal studies are required to elucidate this question.

\section{References}

1. Winter WE, Harris N \& Schatz D (2002). Immunological markers in the diagnosis and prediction of autoimmune type 1 A diabetes. Clinical Diabetes, 20: 183-191.

2. American Diabetes Association (1997). Report of the Expert Committee on the diagnosis and classification of diabetes mellitus. Diabetes Care, 20: 1183-1201.

3. Zimmet PZ (1995). The pathogenesis and prevention of diabetes in adults. Diabetes Care, 18: 1050-1064.

4. Nazaimoon WM, Azmi KN, Rasat R, Ismail IS, Singaraveloo M, Mohamad WB, Letchuman R, Sheriff $I H$, Faridah I \& Khalid BA (2000). Autoimmune markers in young Malaysian patients with type 1 diabetes mellitus. Medical Journal of Malaysia, 55: 318-323.

5. Pardini VC, Mourao DM, Nascimento PD, Vivolo MA, Ferreira SR \& Pardini $H$ (1999). Frequency of islet cell autoantibodies (IA-2 and GAD) in young Brazilian type 1 diabetes patients. Brazilian Journal of Medical and Biological Research, 32: 1195-1198.

6. Yokota I, Matsuda J, Naito E, Ito M, Shima K \& Kuroda Y (1998).
Comparison of GAD and ICA512/IA-2 antibodies at and after the onset of IDDM. Diabetes Care, 21: 49-52.

7. Imagawa A, Itoh N, Hanafusa $T$ et al. (1996). High prevalence of antibodies to glutamic acid decarboxylase in comparison to islet cell antibodies in patients with long-standing insulin-dependent diabetes mellitus. Research Communications in Molecular Pathology and Pharmacology, 92: 43-52.

8. Covic AM, Schelling JR, Constantiner M, lyengar SK \& Sedor JR (2000). Serum C-peptide concentrations poorly phenotype type 2 end-stage renal disease patients. Kidney International, 58: 17421750.

9. Berger B, Stenstrom G \& Sundkvist G (2000). Random C peptide in the classification of diabetes. Scandinavian Journal of Clinical and Laboratory Investigation, 60: 687-693.

10. Cravarezza P, Radaeli E, Toffoli C \& Rigosa C (1986). Discrimination of type I from insulin treated type II diabetic patients by C-peptide measurement. Acta Diabetologica Latina, 23: 345-350. 
11. Palatnik M, Silva Junior WA, Estalote AC, Oliveira JEP, Milech A \& Zago MA (2002). Ethnicity and type 2 diabetes in Rio de Janeiro, Brazil, with a review of the prevalence of the disease in Amerindians. Human Biology, 74: 533-544.

12. Elkadhi A, Khelifi N, Abid A, Nagati K, Jenhani F \& Ben Rayana MC (2002). Prevalence of anti-GAD autoantibodies in Tunisian children with type 1 diabetes. Tunisie Médicale, 80: 281-285.

13. Schmidli RS, DeAizpurua HJ, Harrison LC \& Colman PG (1994). Antibodies to glutamic acid decarboxylase in at-risk and clinical insulin-dependent diabetic subjects: relationship to age, sex and islet cell antibody status, and temporal profile. Journal of Autoimmunity, 7: 55-66.

14. Chen BH, Chung SB, Chiang W \& Chao MC (2001). GAD65 antibody prevalence and association with thyroid antibodies, HLA-DR in Chinese children with type 1 diabetes mellitus. Diabetes Research and Clinical Practice, 54: 27-32.

15. Thai AC, Ng WY, Loke KY, Lee WR, Lui KF \& Cheah JS (1997). AntiGAD antibodies in Chinese patients with youth and adult-onset IDDM and NIDDM. Diabetologia, 40: 1425-1430.

16. Aguilera E, Recasens M, Morinigo RA, Casamitjana R, Oriola J, Ercilla G \& Conget I (2003). Clinical, metabolic, immunologic and genotypic characteristics in non-pediatric patients with type 1A diabetes mellitus. Onset and short-term prognosis. Medicina Clínica, 120: 121-124.

17. Sabbah E, Savola K, Ebeling $T$, Kulmala $P$, Vahasalo $P$, llonen J, Salmela PI \& Knip M (2000). Genetic, autoimmune, and clinical characteristics of childhood and adult onset type 1 diabetes. Diabetes Care, 23: 1326-1332

18. Vandewalle CL, Falorni A, Svanholm S, Lernmark A, Pipeleers DG \& Gorus FK (1995). High diagnostic sensitivity of glutamate decarboxylase autoantibodies in insulin-dependent diabetes mellitus with clinical onset between age 20 and 40 years. The Belgian Diabetes Registry. Journal of Clinical Endocrinology and Metabolism, 80: 846-851.

19. Hosszufalusi N, Vatay A, Rajczy K et al. (2003). Similar genetic features and different islet cell autoantibody pattern of latent autoimmune diabetes in adults (LADA) compared with adult-onset type 1 diabetes with rapid progression. Diabetes Care, 26: 452-457.

20. Prado Jr C (2000). Formação do Brasil Contemporâneo. Editora Brasiliense/Publifolha, São Paulo, SP, Brazil, 81-113.

21. Fernandes APM, Louzada-Junior P, Foss MC \& Donadi EA (2002). HLA DRB1, DQB1 and DQA1 allele profile in Brazilian patients with type 1 diabetes mellitus. Annals of the New York Academy of
Sciences, 958: 305-308

22. Marques SBD, Volpini W, Caillat Zucman S, Leiber SR, Pavin EJ \& Persoli LB (1998). Distribution of HLA-DRB1 alleles in a mixed population with insulin dependent diabetes mellitus from Southeast of Brazil. Brazilian Journal of Medical and Biological Research, 31: 365-368.

23. Panz VR, Kalk WJ, Zouvanis M \& Joffe BI (2000). Distribution of autoantibodies to glutamic acid decarboxylase across the spectrum of diabetes mellitus seen in South Africa. Diabetic Medicine, 17: 524-527.

24. Cesarini PR, Mendonça E, Fernandes V, Silva RC, Morimitsu LK, Garcia FE, Vechiatti S, Miranda WL \& Dib SA (2003). Prevalência dos marcadores imunológicos anti-GAD e anti-IA2 em parentes de primeiro grau de diabéticos do tipo 1 em amostra da população da Grande São Paulo. Revista da Associação Médica Brasileira, 49: 395-400.

25. Chuang LM, Lin CY, Wu HP, Tsai WY, Tai TY \& Lin BJ (1997). AntiGAD65 autoantibody in Taiwanese patients with insulin-dependent diabetes mellitus: effect of HLA on anti-GAD65 positivity and clinical characteristics. Clinical Endocrinology, 47: 455-461.

26. Medici F, Hawa MI, Giorgini A, Panelo A, Solfelix CM, Leslie RD \& Pozzilli P (1999). Antibodies to GAD65 and a tyrosine phosphataselike molecule IA-2ic in Filipino type 1 diabetic patients. Diabetes Care, 22: 1458-1461.

27. Borg H, Gottsater A, Fernlund P \& Sundkvist G (2002). A 12-year prospective study of the relationship between islet antibodies and beta-cell function at and after the diagnosis in patients with adultonset diabetes. Diabetes, 51: 1754-1762

28. Jaeger C, Allendorfer J, Hatziagelaki E, Dyrberg T, Bergis KH, Federling K \& Bretzel RG (1997). Persistent GAD65 antibodies in longstanding IDDM are not associated with residual beta cell function, neuropathy and HLA DR status. Hormone and Metabolic Research, 29: 510-515.

29. Zanone MM, Catalfamo E, Pietropaolo SL, Rabbone I, Sacchetti C, Cerutti F. Trucco M \& Cavallo-Perin P (2003). Glutamic acid decarboxylase and ICA512/IA-2 autoantibodies as disease markers and relationship to residual beta-cell function and glycemic control in young type 1 diabetic patients. Metabolism, 52: 25-29.

30. Hermitte L, Atlan-Gepner C, Dufayet D, Jannot MF, Christofilis MA, Nervi S \& Vialettes B (1998). Diverging evolution of anti-GAD and anti-IA2 antibodies in long-standing diabetes mellitus as a function of age at onset: no association with complications. Diabetic Medicine, 15: 586-591. 